\title{
Fetal Renal Insufficiency Following Trastuzumab Treatment for Breast Cancer in Pregnancy: Case Report und Review of the Current Literature
}

\author{
Ingo Gottschalk ${ }^{\mathrm{a}}$ Christoph Berg ${ }^{\mathrm{a}, \mathrm{b}} \quad$ Nadia Harbeck $^{\mathrm{c}}$ Rüdiger Stressig ${ }^{\mathrm{d}}$ Peter Kozlowski $^{\mathrm{d}}$ \\ aPränatalmedizin und Gynäkologische Sonographie, Klinik und Poliklinik für Frauenheilkunde und Geburtshilfe der Universität zu Köln, \\ ${ }^{\mathrm{b} B}$ Bereich Pränatale Medizin, Universitätsfrauenklinik Bonn, \\ 'Brustzentrum, Klinik und Poliklinik für Frauenheilkunde und Geburtshilfe der Universität zu Köln, \\ ${ }^{d}$ praenatal.de, Pränatal-Medizin und Genetik, Düsseldorf, Germany
}

\section{Keywords}

Fetus · Renal insufficiency · Trastuzumab · Breast cancer . Pregnancy

\section{Summary}

Some drugs are known for their fetal nephrotoxicity and should be avoided during pregnancy. We report on a pregnant woman suffering from breast cancer who received a weekly neoadjuvant trastuzumab (Herceptin ${ }^{\circledR}$ ) therapy from 15 weeks of gestation onward, in addition to a 3-weekly carboplatin/docetaxel chemotherapy. Fetal renal insufficiency with anhydramnios and missing visualization of the fetal bladder developed at 21 weeks. After discontinuation of trastuzumab and repeated instillation of amniotic fluid, the amount of amniotic fluid remained stable after 24 weeks of gestation. After caesarean section at 34 weeks because of fetal growth restriction, the renal function of the neonate was normal postnatally. In accordance with the current literature, our case shows a reversible adverse effect of trastuzumab on the fetal renal function and confirms the current recommendation that trastuzumab in pregnancy should be avoided. In pregnancies exposed to trastuzumab, treatment should be discontinued and the fetus should be closely monitored, with particular attention to the amniotic fluid and the fetal bladder volume, as these reflect fetal renal function.
Schlüsselwörter

Fetus - Niereninsuffizienz - Trastuzumab - Brustkrebs · Schwangerschaft

\section{Zusammenfassung}

Für einige Medikamente sind fötale, nephrotoxische Nebenwirkungen bekannt, weshalb eine Therapie mit diesen Medikamente während einer Schwangerschaft vermieden werden sollte. Wir berichten von einer Schwangeren mit Brustkrebs, die neoadjuvant ab der 15. Schwangerschaftswoche (SSW) zusätzlich zur 3-wöchentlichen Carboplatin/Doxetaxel-Chemotherapie wöchentlich Trastuzumab (Herceptin ${ }^{\circledR}$ ) erhalten hatte. $\mathrm{Ab}$ der 21. SSW zeigte sich ein Anhydramnion als Zeichen einer fötalen Niereninsuffizienz. Eine fötale Harnblasenfüllung war nicht darstellbar. Nach sofortigem Absetzen von Trastuzumab und wiederholter wöchentlicher Fruchtwasserauffüllung normalisierte sich die Fruchtwassermenge dann ab der 24. SSW und blieb im Verlauf normal. Im weiteren Verlauf der Schwangerschaft entwickelte sich eine fötale Wachstumsretardierung, die zur Entbindung durch Sectio caesarea in der 34. SSW führte. Die weitere postnatale Entwicklung sowie die Nierenfunktion des Neonaten waren unauffällig. In Übereinstimmung mit bisherigen Publikationen zeigt unser Fall eine Trastuzumab-bedingte, reversible fötale Niereninsuffizienz und bestätigt somit aktuelle Empfehlungen, eine Therapie mit Trastuzumab in der Schwangerschaft zu vermeiden. Nach erfolgter Gabe in der Schwangerschaft sollte Trastuzumab sofort abgesetzt und die weitere Schwangerschaft engmaschig kontrolliert werden, wobei besonderes Augenmerk auf die Fruchtwassermenge und die fötale Harnblasenfüllung gelegt werden sollte, da diese die adäquate fötale Nierenfunktion widerspiegeln.

\section{KARGER \\ Fax +497614520714 \\ Information@Karger.de}

www.karger.com (c) 2011 S. Karger GmbH, Freiburg

$1661-3791 / 11 / 0066-0475 \$ 38.00 / 0$

Accessible online at:

www.karger.com/brc
Dr. Ingo Gottschalk

Pränatalmedizin und Gynäkologische Sonographie, Klinik und Poliklinik

für Frauenheilkunde und Geburtshilfe der Universität zu Köln

Kerpenerstr. 34, 50931 Köln, Germany

Tel. +49 221 478-4975, Fax -4998

ingo.gottschalk@uk-koeln.de 


\section{Introduction}

Breast cancer in pregnant women is rare, with an incidence of 1 in 3000 live births [1-3]. But with increasingly higher maternal age at time of conception the incidence of malignant diseases in pregnancy is rising. Thus, we are more frequently confronted with the question of compatibility of chemotherapy and pregnancy, and information about possible side effects on the fetus is of increasing clinical relevance [4-12]. The recent literature describes new therapeutic options for breast cancer during pregnancy and proves the feasibility and tolerability of, e.g., anthracycline- or taxane-containing regimens without compromising the fetus [3, 6, 7, 9-35], especially if chemotherapy is administered during the second or third trimester [6, 7, 10-12, 16, 17, 23-25, 36-38].

\section{Case Report}

A 38-year-old pregnant woman at $11+6$ weeks of gestation was diagnosed with an estrogen receptor (ER)/progesterone receptor (PR)-positive, HER2-overexpressing invasive ductal carcinoma of the breast with ductal carcinoma in situ, without further signs of metastatic disease. According to the patient's request, breast-conserving surgery and axillary lymph node dissection were postponed until after delivery. Instead, the decision for neoadjuvant chemotherapy with 3-weekly docetaxel (75 mg/ $\mathrm{m}^{2}$ ) and carboplatin (area under the curve (AUC) 6) (q21d) in addition to weekly trastuzumab (Herceptin ${ }^{\circledR}, 4 \mathrm{mg} / \mathrm{kg}$ ) (Breast Cancer International Research Group (BCIRG)006) was made by the attending, nonlocal physician, and the first and second cycles of taxotere, carboplatin, Herceptin $(\mathrm{TCH})$ were administered at $14+6$ and $17+6$ weeks of gestation, respectively, until the patient was referred to our department at $20+4$ weeks of gestation with anhydramnios and failure to visualize the fetal bladder. As fetal renal insufficiency was suspected, we discontinued trastuzumab therapy immediately and performed weekly instillations of amniotic fluid, as the normal amount of amniotic fluid is crucial for fetal lung maturation and development. After 3 instillations, the amount of amniotic fluid remained stable after 24 weeks of gestation. Simultaneously, neoadjuvant chemotherapy was continued externally again, with docetaxel and carboplatin at $21+0,24+0,27+0$ and $30+0$ weeks of gestation. At 28 weeks of gestation, fetal growth restriction was diagnosed with normal amniotic fluid volume and normal fetal Doppler flow parameters. As the growth restriction worsened, a caesarean section was performed at $33+2$ weeks and a dystrophic premature male neonate was born (birth weight $<3^{\text {rd }}$ percentile). The neonatal period was characterized by inconspicuous neonatal development and normal renal function with normal urinalysis. 13 days post partum, the mother underwent lumpectomy and sentinel lymph node dissection of 2 tumor-free lymph nodes.

\section{Discussion}

Chemotherapy during the first trimester of pregnancy - the time of fetal organogenesis - is associated with an increased incidence of teratogenicity and an increased rate of fetal malformation compared with administration in the second or third trimester [26, 38-42]. Earlier reports with an association of chemotherapy and fetal growth restriction [26, 38-42] could not be confirmed in the recent literature $[10,12,17,36]$.
Whether the growth restriction leading to preterm delivery of a dystrophic neonate in our case was caused by the chemotherapeutic drugs, by trastuzumab or neither of them remains unclear. As Doppler sonography failed to demonstrate any sign of uteroplacental dysfunction, it is most likely drug induced.

If chemotherapy during pregnancy is unavoidable, some chemotherapeutic drugs are considered safer than others and should be used preferably: Contraindicated in pregnancy are the folic acid antagonist methotrexate or aminopterin [43-49], and thus the previously most common adjuvant regimen cyclophosphamide/methotrexate/fluorouracil (CMF) [7]. Other drugs, like the pyrimidine-antagonist 5-fluorouracil, should be avoided during pregnancy because of limited experience in pregnancy [10, 11, 16, 17, 49]. For other drugs, reports are contradictory, e.g. reports on the effect of cyclophosphamide $[7,10,24,37,38,43,50,51]$. Until now, the best body of evidence exists for anthracyclines, mostly because these drugs have also been used for a long time in young women with hematological malignancies [7, 10, 11, 25, 27, 28, 38, 52-58].

In our case, the pregnant woman was exposed to a neoadjuvant docetaxel/carboplatin/trastuzumab regimen. A significant transplacental transfer of platinum-containing drugs like cis- and carboplatin was reported in previous studies from the second trimester of pregnancy onward, but no fetotoxic effect was seen in any of the published cases [51, 29-31, 59-60]. Thus, administration of carboplatin during pregnancy seems to be reasonable and the benefits from its use in pregnancy may be acceptable despite a possible risk for the fetus.

The anti-neoplastic effect of taxanes is based on the inhibition of the synthesis of microtubules. Experience with fetal exposition to taxanes shows no adverse effect on the fetus, and exclusively healthy babies were born [18-23, 26, 30, 31, 33, 34, 61].

Trastuzumab (Herceptin ${ }^{\circledR}$, Roche Pharma AG, GrenzachWhylen, Germany) is a monoclonal IgG1 antibody to the human epidermal growth factor receptor HER2. The transplacental transfer of IgG1 antibodies is documented [62] and has been shown for other IgG1 antibodies like rituximab [63] and infliximab [64]. As HER2 is also expressed in embryofetal tissue, it may be critical for fetal development. Now sufficient reports on trastuzumab-therapy in pregnancy have been published in which serious adverse effects on fetal development were documented to show that trastuzumab in pregnancy is contraindicated [3, 10, 13, 15-17, 32, 35, 65-73]. Most cases report on fetal nephrotoxicity with renal insufficiency with oligo- and anhydramnios [32, 35, 65, 66, 72], but with spontaneous improvement of renal function after discontinuation of trastuzumab. Another case of trastuzumab in pregnancy showed oligohydramnios and vaginal bleeding at 27 weeks of gestation. A caesarean section was performed subsequently for ongoing bleeding. The preterm infant developed respiratory failure, capillary leak syndrome, persistent infections, and necrotizing enterocolitis and ultimately died [71]. 
Three other case reports showed uneventful pregnancies without fetal impairment and with normal fetal growth. Each pregnancy resulted in the birth of a healthy baby [67-69]. Another case described a pregnancy exposed to trastuzumab until 24 weeks of gestation. Therapy was then discontinued because of asymptomatic persistent mildly reduced ejection fraction. The pregnancy was otherwise uneventful. A healthy baby was born at 37 weeks of gestation by caesarean section due to breech presentation. No data on fetal renal function were available [70].

\section{Conclusions}

In accordance with the current literature, our case showed a trastuzumab-induced transient fetal renal insufficiency with anhydramnios, with improvement of amniotic fluid volume and complete remission of renal function after discontinuation of trastuzumab. Although HER2 overexpression is a negative marker for maternal prognosis [74, 75] and a combination of chemotherapy with trastuzumab significantly improves maternal survival, therapy in pregnancy should be avoided. If accidentally exposed to trastuzumab, treatment should be discontinued immediately and the fetus should be closely monitored with particular attention to the amniotic fluid and the fetal bladder volume as these reflect fetal renal function.

\section{Disclosure Statement}

All authors have no financial or personal conflicts of interest.

\section{References}

1 Wallack MK, Wolf JA Jr, Bedwinek J, Denes AE, 12 Cardonick E, Usmani A, Ghaffar S: Perinatal outGlasgow G, Kumar B, Meyer JS, Rigg LA, WilsonKrechel S: Gestational carcinoma of the female breast. Curr Probl Cancer 1983;7:1-58.

2 Merlob P: Infant or mother with malignant disease. Beltis 2004;12:40-49.

3 Barnes DM, Newman LA: Pregnancy-associated breast cancer: A literature review. Surg Clin N Am 2007;417-430.

4 Kelly HL, Collichio FA, Dees EC: Concomitant pregnancy and breast cancer: options for systemic therapy. Breast Dis 2006;23:2005-2095.

$\checkmark 5$ Aziz S, Pervez S, Khan S, Siddiqui T, Kayani N, Israr M, Rahbar M: Case control study of novel prognostic markers and disease outcome in pregnancy/lactation-associated breast carcinoma. Pathol Res Pract 2003;199:15-21.

6 McGrath S, Ring A: Chemotherapy for breast cancer in pregnancy: evidence and guidance for oncologists. Ther Adv Med Oncol 2011;3:73-83.

$\checkmark 7$ Ring AE, Smith IA, Jones A, Shannon C, Galani E, Ellis PA: Chemotherapy for breast cancer during pregnancy: an 18-year experience from five London teaching hospitals. J Clin Oncol 2005;23:4192-4197.

$\checkmark 8$ Reed W, Sandstad B, Holm R, Nesland JM: The prognostic impact of hormone receptors and c-erbB-2 in pregnancy-associated breast cancer and their correlation with BRCA1 and cell cycle modulators. Int J Surg Pathol 2003;11:65-74.

9 German Breast Group, GBG-29: Breast cancer in pregnancy: Prospective register study for the diagnosis and treatment of breast cancer in pregnancy. www.germanbreastgroup.de/pregnancy.

10 Loibl S, Amant F, Kaufmann M, Ring A, Han S, Giermek J, Bontenbal M, Heinrigs M, Jenhard M, Mehta K, von Minckwitz G: 313 patients with breast cancer during pregnancy - results from a prospective and retrospective registry (GBG-20/ BIG02-03). San Antonio Breast Cancer Symposium (SABCS) 2010; abstr 259.

11 Hahn KME, Johnson PH, Gordon N: Treatment of pregnant breast cancer patients and outcomes of children exposed to chemotherapy in utero. Cancer 2006;107:1219-1226. comes of a pregnancy complicated by cancer, including neonatal follow up after in utero exposure to chemotherapy: results of an international registry. Am J Clin Oncol 2010;33:221-228.

13 Loibl S, von Minckwitz G, Gwyn K: Breast carcinoma during pregnancy. International recommendations from an expert meeting. Cancer 2006; 106:237-246.

14 De Carolis S, Grimolizzi F, Garofalo S, Fatigante E, Ferrazzani S, Carducci B, Caruso A: Cancer in pregnancy: results of a series of 32 patients. Anticancer Res 2006;26:2413-2418.

15 Halaska MJ, Pentheroudakis MD, Strnad P, Stankusova H, Chod J, Robova H, Petruzelka L, Rob L, Pavlidis N: Presentation, management and outcome of 32 patients with pregnancy associated breast cancer: a matched controlled study. Breast J 2009;15:461-467.

16 Loibl S: New therapeutic options for breast cancer during pregnancy. Breast Care 2008;3:171-176.

17 Mir O, Berveiller P, Ropert S, Goffinet F, Pons G, Treluyer JM, Goldwasser F: Emerging therapeutic options for breast cancer chemotherapy during pregnancy. Ann Oncol 2008;19:607-613.

18 Gonzales-Angulo AM, Walters RS, Carpenter RJ, Ross MI, Perkins GH, Gwyn K, Theriault RL: Paclitaxel chemotherapy in a pregnant patient with bilateral breast cancer. Clin Breast Cancer 2004:5:317-319.

19 DeSantis M, Lucchese A, De Carolis S, Ferrazzani $\mathrm{S}$, Caruso A: Metastatic breast cancer in pregnancy: first case of chemotherapy with docetaxel. Eur J Cancer 2000;9:235-237.

20 Gainford MC, Clemons M: Breast cancer in pregnancy: are taxanes safe? Clin Oncol 2006;18:159.

21 Potluri V, Lewis D, Burton GV: Chemotherapy with taxanes in breast cancer during pregnancy: case report and review of the literature. Clin Breast Cancer 2006;7:167-170.

22 Nieto Y, Santisteban M, Aramendia JM, FernandezHidalgo O, Garcia-Manero M, Lopez G: Docetaxel administered during pregnancy for inflammatory breast carcinoma. Clin Breast Cancer 2006;6:533534.
23 Gadducci A, Cosio S, Fanucchi A, Nardini V, Roncella M, Conte PF, Genazzani AR: Chemotherapy with epirubicin and paclitaxel for breast cancer during pregnancy: case report and review of the literature. Anticancer Res 2003;23:5225-5229.

24 Koren G, Weiner L, Lishner, M, Zemelickes D, Fingegen J: Cancer and pregnancy: identification of unanswered questions on maternal and fetal risks: Obstet Gynecol Surv 1990;45:509-514.

25 Germann N, Goffinet F, Goldwasser F: Anthracyclines during pregnancy: embryo-fetal outcome in 160 patients. Ann Oncol 2004;15:146-150.

26 Cardonick E, Iacobucci A: Use of chemotherapy during human pregnancy. Lancet Oncol 2004; 5:283-291.

27 Arlin Z, Case DC Jr, Moore J, Wiernik P, Feldman E, Saletan S, Desai P, Sia L, Cartwright K: Randomized multicenter trial of cytosine arabinoside with mitoxantrone or daunorubicin in previously untreated adult patients with acute nonlymphocytic leukaemia (ANLL). Leukemia 1990;4:177-183.

28 Büchner T, Hiddemann W, Wörmann B, et al.: Double induction strategy for acute myoloid leukaemia: the effect of high-dose cytarabine with mitoxantrone instead of standard-dose cytarabine with daunorubicin and 6-thioguanine: a randomized trial by the German AML Cooperative Group. Blood 1999;93:4116-4124.

29 Mir O, Berveiller P, Ropert S, Goffinet F, Goldwasser J: Use of platinum derivates during pregnancy. Cancer 2008;11:3069-3074.

30 Mendez LE, Mueller A, Salom E, GonzalezQuintero VH: Paclitaxel and carboplatin chemotherapy administered during pregnancy for advanced epithelial ovarian cancer. Obstet Gynecol 2003;102:1200-1202.

31 Sood AK, Shahin MS, Sorosky JI: Paclitaxel and platinum chemotherapy for ovarian carcinoma during pregnancy. Gynecol Oncol 2001;83:599-600.

32 Bader AA, Schlembach D, Tamussino KF Pristauz G, Petru E: Anhydramnios associated with administration of trastuzumab and paclitaxel for metastatic breast cancer during pregnancy. Lancet Oncol 2007;8:79-81. 
\$3 Lycette JL, Dul CL, Munar M, Belle D, Chui SY, Koop DR, Nichols CR: Effect of pregnancy on the pharmacokinetics of paclitaxel: a case report. Clin Breast Cancer 2006;7;342-344.

34 Gainfort MC, Clemons M: Breast cancer in pregnancy: are taxanes safe? Clin Oncol 2006;18:159.

-35 Sekar R, Stone PR: Trastuzumab use for metastatic breast cancer in pregnancy. Obstet Gynecol 2007;110:507-510.

36 Cardonick E, Dougherty R, Grana G Gilmandyar D, Ghaffar S, Usmani A: Breas cancer during pregnancy: maternal and fetal outcomes. Cancer J 2010;16:76-82.

\$37 Paladini D, Vassallo M, D'Armiento MR, Cianciaruso B, Martinelli P: Prenatal detection of multiple fetal anomalies following inadvertent exposure to cyclophosphamide in the first trimester of pregnancy. Birth Defects Res A 2004;70:99-100.

$\checkmark 38$ Berry DL, Theirault RL, Holmes FA, Parisi VM, Booser DJ, Singletary SE, Buzdar AU, Hortobagyi GN: Management of breast cancer during pregnancy using a standardized protocol. J Clin Oncol 1999;17:855-861.

39 Schapira DV, Chudley AE: Successful pregnancy following continuous treatment with combination chemotherapy before conception and throughout pregnancy. Cancer 1984;54:800-803.

40 Doll DC, Ringenberg QS, Yarbo JW: Antineoplastic agents and pregnancy. Semin Oncol 1989; 16:337-346.

41 Giacalone PL, Laffargue F, Benos P: Chemotherapy for breast carcinoma during pregnancy: A French national survey. Cancer 1999;86:2266-2272.

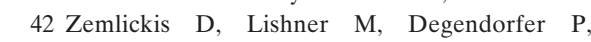
Panzarella T, Burke B, Sutcliffe SB, Koren G Maternal and fetal outcome after breast cancer in pregnancy. Am J Obstet Gynecol 1992;166:781787.

43 Vaux KK, Kahole NCO, Jones KL: Cyclophosphamide, methotrexate and cytarabine embryopathy: Is apotosis the common pathway? Birth Defects Res A 2003;67:403-408.

44 Melzer HJ: Congenital anomalies due to attempted abortion with 4-amino pteroylglutamic acid. JAMA 1956;161:1253.

45 Milunsky A, Graef JW, Gaynor MF: Methotrexate-induced congenital malformations. J Pediatr 1968;72:790-795.

46 Warkary J: Aminopterin und methotrexate: folic acid deficiency. Teratology 1978;17:353-358.

47 Bawle EV, Conard JV, Weiss L: Adult and two children with fetal methotrexate syndrome. Teratology 1998;57:51-55.

48 McElhatton PR: A review of the reproductive toxicity of methotrexate in human pregnancy. Reprod Toxicol 2000;14:549.
49 Paskulin GA, Gazzola Zen PR, Camargo Pinto LL, Rosa R, Graziadio C: Combined chemotherapy and teratogenicity. Birth Defects Res A 2005;73:634-637.

50 Zemlickis D, Lishner M, Ehrlich R, Koren G: Teratogenicity and carcinogenicity in a twin exposed in utero to cyclophosphamide. Teratogen Carcinog Mutagen 1992;13:139-143.

51 Ohara N, Teramoto K: Successful treatment of an advanced cystadenocarcinoma in pregnancy with cisplatin, adriamycin and cyclophosphamid (CAP) regimen. Case report. Clin Exp Obstet Gynecol 2000;2:123-124.

52 Rai KR, Holland JF, Glidewell OJ, et al.: Treatment of acute myelocytic leukemia: a study by the Cancer and Leukemia Group. Blood 1981;58:12031212.

53 Löwenberg B, Downing JR, Burnett A: Acute myeloid leukaemia. N Engl J Med 1999;341:10511062.

54 Harris NL, Jaffe ES, Diebold J, Flandrin G, Muller-Hermelink HK, Vardiman J, Lister TA, Bloomfield CD: The World Health Organization classification of neoplasms of the hematopoietic and lymphoid tissues: report of the Clinical Advisory Committee meeting - Airlie House, Virginia, November 1997. J Clin Oncol 1999;17:3835-3849.

55 Bonadonna G, Zucali R, Monfardini S, deLena M, Uslenghi $\mathrm{C}$ : Combination chemotherapy of Hodgkin's disease with adriamycin, bleomycin, vinblastine, and imidazole carboxamide versus MOPP. Cancer 1975;36:252-259.

56 Diehl V, Franklin J, Pfreundschuh M, et al.: Standard and increased-dose BEACOPP chemotherapy compared with COPP-ABVD for advanced Hodgkin's disease. N Engl J Med 2003; 348:2386-2395.

57 Aviles A, Neri N: Hematological malignancies and pregnancy: A final report of 84 children who received chemotherapy in utero. Clin Lymphoma 2001;3:173-177.

58 Turchi JJ, Villasis C: Anthracycline in the treatment of malignancy in pregnancy. Cancer 1988;61:435-440.

59 Han Jung-Yeo, Nava-Ocampo AA, Kim T-J: Pregnancy outcome after prenatal exposure to bleomycin, etoposide and cisplatin for malignant ovarian germ cell tumors: report of 2 cases. Reprod Toxicol 2005;19:557-561.

60 Peres RM, Sanseverino MTV, Guimararaes JLM, Coser V, Giuliani L, Moreira RK, Ornsten T, Schüler-Faccini L: Assessment of fetal risk associated with exposure to cancer chemotherapy during pregnancy: a multi-center study. Braz J Med Biol Res 2001:34:1551-1559.
61 Mantovani G, Gramignano G, Mais V: Use of chemotherapy for ovarian cancer during human pregnancy: case report and literature review. Eur J Obstet Gynecol Reprod Biol 2007;131:238-239.

62 Simister NE: Placental transport of immunoglobulin G. Vaccine 2003;21:3365-3369.

63 Friedrichs B, Tiemann M, Salwender H, Verpoort K, Wenger MK, Schmitz N: The effects of rituximab treatment during pregnancy on a neonate. Haematologica 2006;91:1426-1427.

64 Vasiliauskas EA, Church JA, Silverman N, Barry M, Targan ST, Dubinsky MC: Case report evidence for transplacental transfer of maternally administered infliximab to the newborn. Clin Gastroenterol Hepatol 2006;4:1225-1228.

65 Watson WJ: Herceptin (trastuzumab) therapy during pregnancy: association with reversible anhydramnions. Obstet Gynecol 2005;105:642-651.

66 Pant S, Landon MB, Blumenfeld M, Farrar W, Shapiro CL: Treatment of breast cancer with trastuzumab during pregnancy. J Clin Oncol 2008; 26:1567-1569.

67 Fanale MA, Uyei AR, Theriault RL, Adam K, Thompson RA: Treatment of metastatic breast cancer with trastuzumab and vinorelbine during pregnancy. Clin Breast Cancer 2005;6:354-356.

68 Waterston AM, Graham J: Effect of adjuvant trastuzumab on pregnancy. J Clin Oncol 2006; 24:321-322.

69 Azim HA Jr, Peccatori FA, Liptrott SJ, Catania C, Goldhirsch A: Breast cancer and pregnancy: how safe is trastuzumab? Nat Rev Clin Oncol 2009;6:367-370.

70 Shrim A, Garcia-Bournissen F, Maxwell C, Farine D, Koren G: Favorable pregnancy outcome following trastuzumab (herceptin) use during pregnancy - Case report and updated literature review. Reprod Toxicol 2007;23:611-613.

71 Witzel ID, Müller V, Harps E, Janicke F, Dewit M: Trastuzumab in pregnancy associated with poor fetal outcome. Ann Oncol 2008;19:191-192.

72 Beale JM, Tuohy J, Mc Dowell SJ: Herceptin (trastuzumab) therapy in a twin pregnancy with associated oligohydramnios. Am J Obstet Gynecol 2009;201:e13-e14.

73 Barthelmes L, Gateley CA: Tamoxifen and pregnancy. Breast 2004;13:446-451.

74 Slamon DJ, Clark GM, Wong SG, Levin WJ, Ullrich A, McGuire WL: Human breast cancer: correlation of relapse and survival with amplification of HER2/neu oncogene. Science 1987;235:177182.

75 Sotiron C, Pusztai L: Molecular origin of cancer gene-expression signatures in breast cancer. N Engl J Med 2009;360:790. 